\title{
PENGARUH ELECTRONIC WORD OF MOUTH TERHADAP KEPUTUSAN BERKUNJUNG DI DESA WISATA CIBEUSI KABUPATEN SUBANG
}

\author{
Nova Riana ${ }^{1}$ \\ Sekolah Tinggi Ilmu Ekonomi Pariwisata Yapari \\ nova.riana@ymail.com \\ Rieke Sri Rizki ${ }^{2}$ \\ Sekolah Tinggi Ilmu Ekonomi Pariwisata Yapari \\ rsrak17@yahoo.com \\ Satria Delonika Regiawan ${ }^{3}$ \\ Sekolah Tinggi Ilmu Ekonomi Pariwisata Yapari \\ satria.delonika@gmail.com
}

\begin{abstract}
This study aims to determine the effect of Electronic Word of Mouth on visit decision in Tourism Village Cibeusi Subang Regency. The research method used is a quantitative method with descriptive and verificative approach. The data used in this study including primary and secondary data. The samples amounted on 100 respondents, taken from the tourist population in 2018 counted as 3.218 tourists . This sample is calculated by using the Slovin formula. The sampling technique is done using incidental approach. Data collection is done using observation, questionnaire, interview and documentation. The model of the questionnaire used a Likert scale. The verificative analysis used were instrumental test (validity test and reliability test), normality test, heteroscedascity test, simple linear regression, correlation analysis, analysis of determination and partial hypothesis test.

The results of this study showed that the correlation between variables categorized as moderate. The effect of the independent variable on the dependent variable was $23.7 \%$, whilst $76.3 \%$ was influenced by other variables not examined in this study. The t test result showed that the value of $t_{\text {count }}>t_{\text {table }}(5,512>1,984)$ with a significance of $0,000<0.05$, so it can be concluded that the Electronic Word of Mouth has a positive and significant effect on the decision to visit Cibeusi Tourism Village, Subang Regency.
\end{abstract}

Key Words: Electronic Word of Mouth, Visit Decision, Tourism Village Cibeusi

\begin{abstract}
ABSTRAK
Penelitian ini bertujuan untuk mengetahui bagaimana pengaruh Electronic Word of Mouth terhadap keputusan berkunjung di Desa Wisata Cibeusi Kabupaten Subang. Metode penelitian yang digunakan yaitu kuantitatif dengan pendekatan deskriptif dan verifikatif. Jenis data yang digunakan dalam penelitian ini yaitu data primer dan data sekunder. Sampel yang digunakan berjumlah 100 responden, hasil dari populasi wisatawan tahun 2018 sebanyak 3.218 wisatawan dan dihitung dengan menggunakan rumus Slovin. Teknik pengambilan sampel dilakukan dengan pendekatan insidental. Pengumpulan data dilakukan dengan teknik observasi, kuesioner, wawancara dan dokumentasi. Model kuesioner dalam penelitian ini
\end{abstract}


menggunakan skala Likert. Analisis verifikatif yang digunakan dalam penelitian ini yaitu uji instrumen (uji validitas dan uji realibilitas), uji normalitas, uji heteroskedastisitas, analisis regresi linier sederhana, analisis korelasi, analisis determinasi dan uji hipotesis parsial.

Hasil penelitian ini menunjukkan bahwa korelasi antara variabel dikategorikan sedang. Pengaruh variabel independen terhadap variabel dependen dalam penelitian ini sebesar $23,7 \%$ sedangkan $76,3 \%$ dipengaruhi variabel lain yang tidak diteliti dalam penelitian ini. Hasil uji t menunjukkan bahwa nilai thitung $>t_{\text {tabel }}(5,512>1,984)$ dengan signifikansi $0,000<0,05$, sehingga dapat disimpulkan bahwa Electronic Word of Mouth berpengaruh dan signifikan terhadap keputusan berkunjung di Desa Wisata Cibeusi Kabupaten Subang

\section{Kata Kunci: Electronic Word of Mouth, Keputusan Berkunjung, Desa Wisata Cibeusi}

\section{PENDAHULUAN}

Indonesia adalah negara dengan keberagaman suku, budaya, flora dan fauna, di mana setiap daerah memiliki berbagai macam potensi wisata, baik wisata alam maupun buatan. Dengan keunikan yang dimilikinya, setiap daerah memiliki potensi untuk menarik perhatian wisatawan domestik dan mancanegara berkunjung. Salah satu daerah yang kaya akan destinasi wisata adalah Jawa Barat. Salah satu Kabupaten di Jawa Barat yang memiliki beragam daya tarik wisata adalah Kabupaten Subang. Jika dilihat dari kondisi geografis, Kabupaten ini memiliki beragam kondisi geografis dan topografis (daerah pegunungan, pantai dan pedataran), kondisi iklim yang cukup sejuk di wilayah selatan karena dikelilingi pegunungan dan cukup panas di wilayah pedataran maupun pantai. Karenanya, dengan berbagai daya tarik wisata alam maupun buatan, seperti Gunung Tangkuban Perahu, Sari Ater, Bumi, Sumber Mata Air Cimuncul, Pondok Bali, Pantai Kalapa Patimban dll, pesona yang dimiliki daya tarik wisata di Kabupaten Subang telah menyumbang pendapatan ekonomi melalui kunjungan wisatawan.

Di Kabupaten Subang ini terdapat beberapa desa wisata seperti Desa Wisata Cibeusi, Desa Wisata Cibuluh, Desa Wisata Bunihayu dll yang masih dikategorikan Desa Wisata Embrio. Desa Wisata Cibeusi berada di Kecamatan Ciater, Kabupaten Subang, Jawa Barat merupakan Desa Wisata unggulan Kabupaten Subang. Terkenal karena lingkungan asri, beberapa daya tarik wisata alam, budaya hingga kuliner yang ditawarkan seperti melakukan kegiatan keseharian masyarakat lokal Desa Cibeusi.

Kegiatan pemasaran menjadi salah satu cara efektif dalam meningkatkan kunjungan wisatawan. Namun, kegiatan pemasaran yang dilakukan desa dan pengelola daya tarik wisata Desa Wisata Cibeusi masih kurang efektif. Ini dapat dilihat dari ketersediaan brosur yang hanya bisa didapatkan di Kantor Desa dan peta yang ada di parkiran Curug Cibareubeuy, sehingga mengakibatkan beberapa daya tarik wisata, terutama budaya, masih kurang dikenal di kalangan wisatawan. Saat ini, Desa Wisata Cibeusi hanya mengandalkan rekomendasi yang dilakukan wisatawan yang pernah mengunjungi, sehingga wisatawan turut membantu menumbuhkan minat berkunjung yang berdampak pada keputusan berkunjung.

Words of Mouth merupakan rekomendasi yang dilakukan wisatawan terhadap calon wisatawan lainnya. Namun, seiring perkembangan internet dan teknologi informasi, Word of Mouth mengalami modernisasi menjadi Electronic Words of Mouth, sehingga mudah terjadi pertukaran informasi dari satu wisatawan ke calon wisatawan lainnya melalui jejaring sosial maupun ulasan di website forum diskusi seperti google review. Unggahan foto maupun komentar pada jejaring sosial maupun website, tentang daya tarik wisata menarik minat wisatawan lainnya untuk mengunjungi daya tarik wisata yang penyebarannya informasi cenderung lebih cepat.

Wisatawan ketika berkunjung, menyampaikannya melalui jejaring sosial maupun forum diskusi. Hal tersebut menjadi kekuatan Electronic Words of Mouth dalam menarik minat wisatawan lainnya untuk berkunjung ke Desa Wisata Cibeusi. Tetapi, bila terjadi 
ketidakpuasan wisatawan selama berkunjung akan menimbulkan Electronic Words of Mouth yang negatif, sehingga membuat wisatawan lainnya enggan untuk datang.

Pemasaran adalah salah satu dari kegiatan pokok yang dilakukan para pengusaha dalam usahanya untuk mempertahankan kelangsungan hidupnya, berkembang, dan menetapkan laba serta memiliki peranan dalam memuaskan kebutuhan pelanggan dan keinginan konsumen dengan penyediaan produk melalui perencanaan. Menurut Philip Kotler dan Kevin Lane Keller (2016:27) pemasaran adalah: "Pemasaran adalah suatu fungsi organisasi dan serangkaian proses untuk menciptakan, mengkomunikasikan dan memberi nilai kepada pelanggan dan untuk mengelola hubungan pelanggan dengan cara yang menguntungkan organisasi dan pemangku kepentingannya". Kotler dan Armstrong (2018:27) mendefinisikan marketing is engaging customers and managing profitable customer relationships. The aim of marketing is to create value for customers in order to capture value from customers in return.

Buchari Alma (2016:205) menjelaskan marketing mix sebagai suatu strategi mencampuri kegiatan-kegiatan pemasaran, agar dicari kombinasi maksimal sehingga mendatangkan hasil yang memuaskan. Marketing mix terdiri atas empat komponen atau disebut $4 \mathrm{P}$ yaitu product, price, place dan promotion. Adapun pengertian $7 \mathrm{P}$ dalam bauran pemasaran menurut Kotler dan Amstrong (2016:62) sebagai berikut: (1) Produk (Product), (2) Harga (Price), (3) Distribusi (Place), (4) Promosi (Promotion), (5) Orang (People), (6) Fasilitas Fisik (Physical Evidence) dan (7) Proses (Process)

Menurut Shinta (2011:127), pengertian promosi adalah: "Suatu bentuk komunikasi pemasaran. Komunikasi pemasaran adalah aktivitas pemasaran yang berusaha untuk menyebarkan informasi, mempengaruhi atau membujuk dan mengingatkan pasar sasaran atau perusahaan dan produknya agar bersedia menerima, membeli dan loyal pada produk yang ditawarkan perusahaan yang bersangkutan". Pada intinya yaitu promosi merupakan kegiatan memberikan atau menyebarkan informasi kepada konsumen yang dapat mempengaruhi konsumen untuk melakukan pembelian.

Perpaduan alat promosi yang digunakan perusahaan untuk membujuk pelanggan dan membangun hubungan dengan pelanggan. Hal ini sejalan pernyataan Kotler dan Armstrong (2018:424-425) bahwa "The specific blend of promotion tools that the company uses to persuasively communicate customer value and build customer relationship." Sedangkan menurut Ali Hasan (2015:259), dinyatakan bahwa Bauran promosi pariwisata adalah kombinasi dari periklanan, promosi penjualan, penjualan pribadi, direct marketing, word of mouth untuk mencapai target penjualan.

Illah dkk, (2019:165) menyatakan bahwa Word of Mouth merupakan media promosi yang dianggap sebagai opini paling jujur dari seorang konsumen. Namun, sekarang jenis promosi tersebut tidak hanya terjadi secara offline, tapi juga bisa secara online mengikuti kemajuan teknologi secara informasi. e-WOM yang terjadi secara online disebut Electronic Word of Mouth (e-WOM). Electronic Word of Mouth (e-WOM) merupakan bentuk komunikasi pemasaran yang berisi tentang pernyataan positif atau negatif yang dilakukan pelanggan

potensial, pelanggan maupun mantan pelanggan tentang suatu produk (Hennig-Thurau dkk.,2004:39). Sedangkan Gruen (2006:6) mendefinisikan Electronic Word of Mouth adalah sebuah media komunikasi untuk saling berbagi komunikasi mengenai suatu produk atau jasa yang telah dikonsumsi antar konsumen yang tidak saling mengenal dan bertemu sebelumnya. Goldsmith dan Horowitz (2006:3) mengungkapkan bahwa di dunia online, ada bermacammacam cara dimana konsumen dapat bertukar informasi. Pengguna internet dapat melakukan Electronic Word of Mouth melalui berbagai saluran online, termasuk blog, mikroblog, email, situs ulasan (review) konsumen, forum, komunitas konsumen virtual, dan situs jejaring sosial.

Menurut Stefes dan Burges dalam Wibowo (2015:73), dinyatakan bahwa informasi yang diperoleh dari forum $e-W O M$ lebih berpengaruh dalam pengambilan keputusan daripada 
berbicara dengan teman-teman secara pribadi (WOM). Sedangkan menurut Humaira dan Wibowo (2016:1051) bahwa e-WOM merupakan digitalisasi dari WOM tradisional. WOM disampaikan secara langsung dari satu pihak ke pihak lain sedangkan penyampaian $e$-WOM membutuhkan media perantara yaitu melalui media elektronik. WOM pada dasarnya berisikan informasi yang akurat, emosional, lebih jujur dan hanya dapat diperoleh sekali saja karena prosesnya terjadi langsung dan berasal dari sumber yang dipercaya contohnya keluarga. Sedangkan $e-W O M$ belum tentu berisi informasi yang akurat karena berasal dari sumber yang cenderung tidak dikenal (misalnya sesama pengguna internet dan media sosial tertentu) namun mempunyai kelebihan yaitu dapat disimpan sebagai arsip jika sewaktu-waktu dibutuhkan dan penyebarannya pun sangat cepat bahkan dapat meluas secara global".

Thurau et. Al dalam Susilawati (2017:34) terdapat 8 dimensi yang paling mempengaruhi seseorang dalam melakukan komunikasi e-WOM. Yaitu : (1) Platform assistance, (2) Venting negative feeling, (3) Concern for other consumers, (4) Extraversion/Positive self-enchanment, (5). Social benefits, (6) Economic incentives, (7) Helping the company, (8) Advice seeking, (9) advice seeking. Dalam konteks berbasis web opinion platform, konsumsi terjadi ketika individu membaca ulasan produk dan komentar yang ditulis orang lain, sehingga dapat memotivasi konsumen menulis komentar. Dalam penelitian ini, penulis tidak menggunakan dimensi economic incentives, karena dimensi ini seperti model endorsment dan pihak Desa tidak melakukan hal tsb kepada pengunjung.

Keputusan pembelian yaitu merupakan proses bagi konsumen untuk mengevaluasi suatu produk yang nantinya akan dipilih dan berpengaruh terhadap keputusan pembelian. Hal ini sesuai dengan pernyataan Fandy Tjiptono (2014:21), bahwa Keputusan pembelian adalah sebuah proses dimana konsumen mengenal masalahnya, mencari informasi mengenai produk atau merek tertentu dan mengevaluasi seberapa baik masing-masing alternatif tersebut dapat memecahkan masalahnya, yang kemudian mengarah kepada keputusan pembelian.

Kotler dan Keller (2016:195-201) menyatakan bahwa perilaku konsumen akan menentukan proses pengambilan keputusan dalam pembelian mereka. Proses pengambilan keputusan tersebut merupakan sebuah pendekatan penyelesaian masalah yang terdiri atas lima tahap yaitu: (1) Pengenalan Kebutuhan, (2) Pencarian Informasi, (3) Evaluasi Alternatif, (4) Keputusan Pembelian dan (5) perilaku pasca pembelian. Jadi, setelah keputusan pembelian, maka konsumen harus mengambil keputusan apakah membeli atau tidak. Bila konsumen memutuskan membeli, konsumen akan menjumpai serangkaian keputusan yang harus diambil menyangkut jenis produk, merek, penjual, kuantitas, waktu pembelian dan cara pembayarannya. Perusahaan perlu mengetahui beberapa jawaban atas pertanyaan yang menyangkut perilaku konsumen dalam keputuan pembeliannya.

Cara yang dilakukan konsumen dalam melakukan tahapan keputusan pembelian dipengaruhi oleh beberapa faktor diantaranya adalah level keterlibatan konsumen (consumer involvement) dalam pemilihan suatu produk. Consumer involvement dibagi menjadi dua yaitu : (1) Low Involment dan (2) High Involment. Dalam tahap perilaku pasca pembelian terjadi kepuasan pasca pembelian, tindakan pasca pembelian, dan penggunaan produk pasca pembelian.

Seorang konsumen akan merasa puas, jika harapannya terhadap produk dapat dipenuhi. Jika tidak terpenuhi oleh performa produk yang dikonsumsinya, maka konsumen akan merasa kecewa dan tidak puas hingga memberi tahu kepada orang lain dengan image negatif dengan sangat cepat. Sebaliknya, jika harapannya terpenuhi, maka akan merasa puas bahkan merekomendasikan terhadap orang lain. Penilaian kepuasan pelanggan mempunyai tiga nilai berbeda: (a) Nilai harapan = nilai persepsi: konsumen puas, (b) Nilai harapan $<$ nilai persepsi: konsumen sangat puas dan (c) Nilai harapan > nilai persepsi: konsumen tidak puas.

Ada beberapa faktor yang mempengaruhi kepuasan pelanggan diantaranya: (1) Apa yang didengar pelanggan dari pelanggan lainnya (Word of Mouth communication).(2) 
Ekspektasi pelanggan sangat bergantung dari karakteristik individu dimana kebutuhan pribadi (personnel needs), (3) Pengalaman masa lalu (past experience) dalam menggunakan pelayanan, (4) Harga untuk pelanggan yang sensitive menjadi sumber kepuasan penting karena pelanggan mendapatkan value for money yang tinggi, (5) Komunikasi melalui iklan dan pemasaran juga mempengaruhi persepsi pelanggan.

Menurut Zeithaml dan Bitner (2013:75) terdapat 3 faktor yang mempengaruhi kepuasan pelanggan seperti pada gambar berikut:

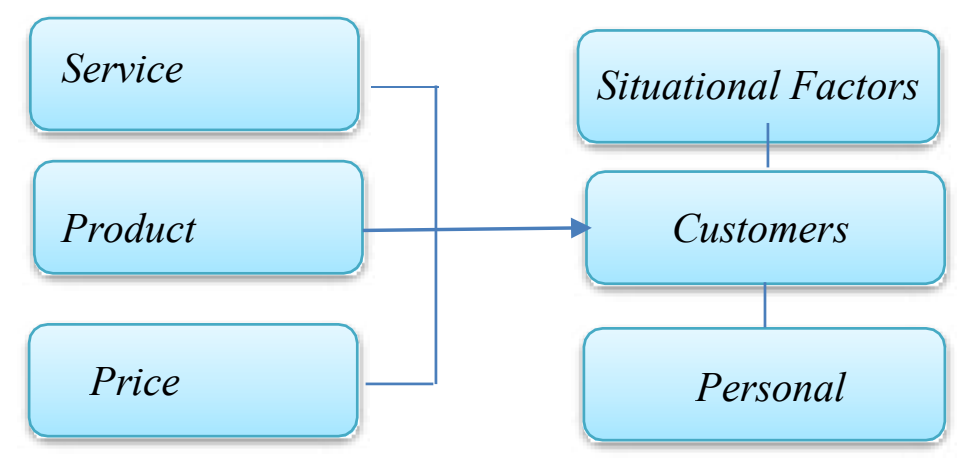

Gambar 2:

Faktor-faktor Yang Berpengaruh pada Kepuasan Pelanggan

Sumber: Zeithaml dan Bitner (2013:75)

Kepuasan atau ketidakpuasan konsumen terhadap sebuah produk dapat mempengaruhi perilaku konsumen tersebut di masa datang. Jika konsumen puas, kemungkinan besar konsumen akan melakukan pembelian ulang atau kunjungan ulang. Sebaliknya, jika tidak merasa puas, konsumen akan merasa kapok dan bahkan tidak akan membelinya kembali, mengembalikannya, dan mengabaikannya serta memberitahukan kepada sumber informasi yang penting tersebut. Konsumen yang tidak puas dapat melakukan penyampaian keluhan kepada perusahaan, tindakan hukum, mengadu kepada kelompok seperti lembaga perlindungan konsumen, lembaga pemerintah, dan memperingati orang lain untuk tidak memakai produk atau jasa tersebut sehingga perusahaan dapat kehilangan lebih pelanggan.

Tahap-tahap proses kegiatan pembelian konsumen

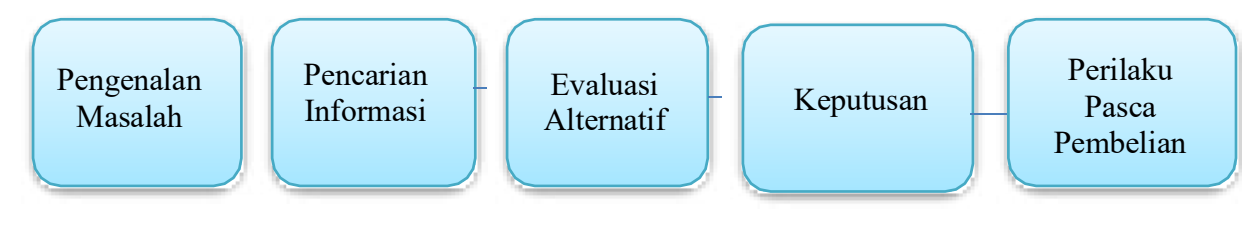

\section{Gambar 3 \\ 5 Tahapan Model Proses Pembelian Konsumen \\ Sumber : Kotler dan Keller (2016:195)}

Menurut Mathieson dan Wall dalam Muksin (2018:198), Keputusan melakukan perjalanan wisata adalah keputusan "pembelian" yang mengeluarkan uang untuk mendapatkan kepuasan. Namun, pembelian dalam konteks pariwisata mempunyai beberapa keleluasaan, paling tidak dalam hal-hal dibawah ini : (1) Produk adalah produk intangible, berupa pengalaman (experience). Meskipun ada bagian dari produk yang tangible (seperti cenderamata), tetapi preparasinya sangat kecil terhadap total nilai pembelian, (2) Nilai 
pembelian umumnya besar dibandingkan dengan pembelian barang-barang lainnya, (3) Pembelian tidak bersifat spontan, perjalanan wisata pada umumnya direncanakan jauh hari sebelumnya, termasuk perencanaan aspek finansial, pemilihan jenis akomodasi, transportasi, dan seterusnya, (4) Untuk menikmati produk yang dibeli, wisatawan harus mengunjungi daerah tujuan wisata secara langsung, berbeda dengan produk lain yang dapat dikirim kepada pembeli. Produk yang dibeli dalam pariwisata tidak dapat disimpan untuk dinikmati pada waktu yang berbeda dan (5) Bagi sebagian wisatawan, mereka tidaklah distante minimized bahkan menganggap perjalanan panjang sebagai bagian dari produk wisata yang dibeli.

Menurut Kotler dan Keller (2016:11), Keputusan pembelian memiliki beberapa dimensi yaitu (1) Pemilihan Produk, (2) Pemilihan Brand (Merek), (3) Pemilihan Penyalur, (4) Jumlah Pembelian, (5) Penentuan Waktu Kunjungan, dan (6) Metode Pembayaran

Arwiedya dalam Hasan \& Setiyaningtiyas (2015:228) menyatakan bahwa dalam media promosi yang berpengaruh terhadap keputusan pembelian, salah satunya ialah online Word of Mouth. Online Word of Mouth merupakan proses komunikasi interpersonal antara dua bahkan beberapa orang yang mempunyai pengaruh atas keputusan pembelian dengan menggunakan media intenet atau web.

\section{METODOLOGI}

Metode yang digunakan dalam penelitian ini adalah metode deskriptif kuantitatif dan verifikatif yang menghitung besarnya pengaruh electronic words of mouth terhadap keputusan berkunjung wisatawan ke Desa Wisata Cibeusi, Kabupaten Subang. Populasi adalah 3.218 wisatawan, dengan sampel sebanyak 100 wisatawan (dari penghitungan Slovin Formula dengan kelonggaran 10\%. Teknik Pengambilan Sampel adalah Insidental sampling. Sedangkan Teknik Pengumpulan Data: (1) Observasi, (2) Kuesioner, (3) Wawancara dan (4) Dokumentasi

Penelitian ini membahas dua variabel yaitu (1) Variabel Independen (Bebas) yaitu Variabel Electronic Word of Mouth sebagai (X) dan Variabel Dependen (Terikat) yaitu Variabel (Y) keputusan berkunjung di Desa Wisata Cibeusi. Berikut adalah tabel operasional variabel dalam penelitian ini:

Tabel 1

Operasional Variabel

\begin{tabular}{|c|c|c|c|c|}
\hline Variabel & Definisi & Dimensi & Indikator & Skala \\
\hline \multirow[t]{5}{*}{$\begin{array}{l}e-W O M \\
(\mathrm{X})\end{array}$} & \multirow{5}{*}{$\begin{array}{l}\text { Electronic Word of Mouth (e- } \\
\text { WOM) merupakan bentuk } \\
\text { komunikasi pemasaran yang } \\
\text { berisi tentang pernyataan } \\
\text { positif atau negatif yang } \\
\text { dilakukan pelanggan } \\
\text { potensial, pelanggan maupun } \\
\text { mantan pelanggan tentang } \\
\text { suatu produk. } \\
\text { Hennig-Thurau et al., } \\
(2004: 39) \text {. }\end{array}$} & a. Platform assistance & $\begin{array}{l}\text { 1. Internet mempermudah Word of } \\
\text { Mouth } \\
\text { 2. Jejaring sosial dan forum dapat } \\
\text { menjadi pertukaran informasi }\end{array}$ & Ordinal \\
\hline & & $\begin{array}{l}\text { b. Venting negative } \\
\text { feelings }\end{array}$ & $\begin{array}{l}\text { 1. Mendapat informasi negatif } \\
\text { 2. Merasakan ketidakpuasan }\end{array}$ & Ordinal \\
\hline & & $\begin{array}{l}\text { c. Concern for other } \\
\text { consumers }\end{array}$ & $\begin{array}{l}\text { 1. Mendapat rekomendasi } \\
\text { 2. Merasakan kepedulian } \\
\text { 3. Merekomendasikan ulang }\end{array}$ & Ordinal \\
\hline & & $\begin{array}{l}\text { d. Extraversion/positive } \\
\text { self-enchanment }\end{array}$ & $\begin{array}{l}\text { 1. Merasakan kebahagiaan orang lain } \\
\text { 2. Mendapat informasi positif }\end{array}$ & Ordinal \\
\hline & & e. Social benefit & $\begin{array}{l}\text { 1. Keinginan berbagi informasi } \\
\text { 2. Keinginan berinteraksi dengan } \\
\text { lingkungan sosial }\end{array}$ & Ordinal \\
\hline
\end{tabular}




\begin{tabular}{|c|c|c|c|c|}
\hline Variabel & Definisi & Dimensi & Indikator & Skala \\
\hline & & f. Helping the company & $\begin{array}{l}\text { 1. Membantu promosi } \\
\text { 2. Membantu publisitas } \\
\text { 3. Membantu meningkatkan } \\
\text { kunjungan }\end{array}$ & Ordinal \\
\hline & & g. Advice Seeking & 1. Mencari saran & Ordinal \\
\hline \multirow{6}{*}{$\begin{array}{l}\text { Keputusan } \\
\text { Berkunjung } \\
\quad(\mathrm{Y})\end{array}$} & \multirow{6}{*}{$\begin{array}{l}\text { Keputusan melakukan } \\
\text { perjalanan wisata adalah } \\
\text { keputusan "pembelian" yang } \\
\text { mengeluarkan uang untuk } \\
\text { mendapatkan kepuasan. } \\
\text { Mathieson dan Wall dalam } \\
\text { Muksin (2018:198). }\end{array}$} & a. Pemilihan Produk & $\begin{array}{l}\text { 1. Berdasarkan daya tarik } \\
\text { 2. Pemilihan Desa Wisata }\end{array}$ & Ordinal \\
\hline & & b. Pemilihan Brand & $\begin{array}{l}\text { 1. Berkunjung berdasarkan keinginan } \\
\text { 2. Berkunjung berdasarkan } \\
\text { popularitas }\end{array}$ & Ordinal \\
\hline & & c. Jumlah Pembelian & $\begin{array}{l}\text { 1. Akan mengunjungi kembali } \\
\text { 2. Lama berkunjung }\end{array}$ & Ordinal \\
\hline & & d. Pemilihan Penyalur & $\begin{array}{l}\text { 1. Berkunjung berdasarkan harga } \\
\text { 2. Berkunjung menggunakan agen } \\
\text { perjalanan }\end{array}$ & Ordinal \\
\hline & & $\begin{array}{l}\text { e. Penentuan Waktu } \\
\text { Kunjungan }\end{array}$ & 1. Berkunjung sesuai waktu & Ordinal \\
\hline & & f. Metode Pembayaran & 1. Pembayaran menggunakan tunai & Ordinal \\
\hline
\end{tabular}

\section{Teknik Analisis}

Dalam penelitian ini, jenis kuesioner yang digunakan adalah kuesioner tertutup yaitu kuesioner yang jawabannya sudah disediakan oleh peneliti, dengan menggunakan skala Likert. Variabel penelitian ini yaitu Electronic Word of Mouth dan keputusan berkunjung. Hasil dari penyebaran kuesioner selanjutnya dicari rata-ratanya dengan menggunakan rumus dari Husein Umar (2011:130)

$$
\text { WWWlanNNNrata }- \text { rata }=\frac{\sum(\| \text { rekuens } \| \text { xbobot })}{\sum \operatorname{sampel}(n)}
$$

Setelah dapat menghitung nilai skor maka selanjutnya mengklasifikasikan jawaban responden ke dalam bentuk interval dengan rumus sebagai berikut:

$$
\begin{aligned}
& \text { Interval }=\frac{\text { KelasMaks } \| \text { mum }- \text { KelasM }\|n\| m u m}{\text { KelasInterval }} \\
& \text { Interval }=\frac{5-1}{5}=0,8
\end{aligned}
$$

Dengan demikian kategori skala setiap pertanyaan dari variabel dapat dikelompokkan sebagai berikut:

Tabel 2.

\section{Tafsiran Nilai Rata-Rata}

\begin{tabular}{|c|c|}
\hline Interval & Kriteria \\
\hline $1,00-1,80$ & Sangat Tidak Baik/Sangat Tidak Setuju \\
\hline
\end{tabular}




\begin{tabular}{|c|c|}
\hline $1,81-2,60$ & Tidak Baik/Tidak Setuju \\
\hline $2,61-3,40$ & Cukup/Ragu - Ragu \\
\hline $3,41-4,20$ & Baik/Setuju \\
\hline $4,21-5,00$ & Sangat Baik/Sangat Setuju \\
\hline
\end{tabular}

Sumber: Husein Umar (2011:10)

\section{Analisis Verifikatif}

Data dalam penelitian ini dirubah menjadi data interval (Method of Successive Interval/ MSI) dengan menggunakan program komputer Microsoft Excel.

\section{Uji Validitas}

Sugiyono (2017:168) menyatakan bahwa pengujian validitas adalah suatu teknik mengukur ketepatan antara data yang terkumpul dengan data yang sesungguhnya terjadi pada obyek yang diteliti. Menurut Sugiyono (2014:134), biasanya syarat minimum untuk dianggap memenuhi syarat adalah sebagai berikut: (1) Jika $r \geq 0,30$, maka item-item pertanyaan dari kuesioner adalah valid, dan (2) Jika $r \leq 0,30$, maka item-item pertanyaan dari kuesioner adalah tidak valid.

Rumus yang digunakan adalah rumus Korelasi Product Moment menurut Sugiyono (2014:183) sebagai berikut:

Keterangan :

$$
r_{x y}=\frac{n \sum x y-\left(\sum x\right)\left(\sum y\right)}{\sqrt{\left\{n \sum x^{2}-\left(\sum x\right)^{2}\right\}\left\{n \sum y^{2}-\left(\sum y\right)^{2}\right\}}}
$$

$\begin{array}{lc}r_{x y} & : \text { Koefisien Korelasi } \\ n & \quad \text { : Banyaknya Sampel } \\ \sum x & \text { : Jumlah skor dalam distribusi X } \\ \sum y & \text { : Jumlah skor dalam distribusi Y }\end{array}$

\section{Uji Reliabilitas}

Dilakukan untuk mengetahui seberapa jauh hasil pengukuran dua kali atau lebih terhadap gejala yang sama dengan menggunakan alat pengukur yang sama. Menurut Sugiyono (2014:121), Reliabilitas adalah instrumen yang bila digunakan beberapa kali untuk mengukur obyek yang sama, akan menghasilkan data yang sama. Untuk melihat reliabilitas masingmasing instrumen yang digunakan, penulis menggunakan koefisien Cronbach Alpha dengan menggunakan SPSS 26 for windows. Nunnally dalam Ghozali (2016:48) mengungkapkan suatu variabel dikatakan reliabel jika memiliki nilai Cronbach Alpha $>0,7$. Menurut Arikunto (2010:164), Pengujian realibilitas instrumen dengan Alpha Cronbach, karena penelitian ini berbentuk angket dan skala bertingkat. Rumus Alpha Crokzach sebagai berikut:

Keterangan :

$$
r_{11}=\underset{(n-1)}{\left(\frac{n}{2}\right)}\left(1-\frac{{ }^{\sigma^{2}}}{\sigma_{t^{2}}}\right)
$$

$$
\begin{array}{ll}
r_{11} & =\text { realibilitas yang dicari } \\
n & =\text { jumlah item pertanyaan yang diuji } \\
\sum \sigma_{t^{2}} & =\text { Jumlah varians skor tiap item } \\
\sigma_{t^{2}} & =\text { varians total }
\end{array}
$$




\section{Uji Normalitas}

Menurut Ghozali (2016:154) uji normalitas dilakukan untuk menguji apakah dalam model regresi variabel independen dan variabel dependen atau keduanya mempunyai distribusi normal atau tidak. Apabila variabel tidak berdistribusi secara normal, maka hasil uji statistik akan mengalami penurunan. Uji normalitas data dapat dilakukan dengan menggunakan One Sample Kolmogorov Smirnov dalam program SPSS. Menurut Santoso (2012:393) dasar pengambilan keputusan dilakukan berdasarkan probabilitas (Asymtotic Significanted) yaitu jika probabilitas $>0,05$ maka distribusi dari model regresi adalah normal. Sedangkan jika probabilitas $<0,05$ maka distribusi dari model regresi adalah tidak normal.

\section{Analisis Regresi Linier Sederhana}

Menurut Sugiyono (2014:261) analisis regresi linier sederhana adalah regresi sederhana didasarkan pada hubungan fungsional atau kausal satu variabel independen dengan satu variabel dependen. Analisis ini untuk mengetahui adakah pengaruh antara variabel independen dengan variabel dependen apakah ada pengaruh positif atau negatif. Rumus regresi linier sederhana adalah sebagai berikut:

$$
Y=a+b b b b b
$$

Sumber: Sugiyono (2017:188)

\section{Analisis Korelasi}

Analisis korelasi sederhana (Bivariate Correlation) ini digunakan untuk mengetahui keeratan hubungan antara indikator variabel Electronic Word of Mouth terhadap keputusan berkunjung. dan untuk mengetahui arah hubungan yang terjadi. Koefisien korelasi sederhana menunjukkan seberapa besar hubungan yang terjadi antara dua variabel. Untuk dapat memberikan penafsiran terhadap koefisien korelasi yang ditemukan tersebut besar atau kecil, maka dapat berpedoman pada ketentuan yang dikemukakan Sugiyono (2017:184) seperti tertera pada tabel berikut:

Tabel 3

\section{Interprestasi Koefisien Korelasi}

\begin{tabular}{|c|c|}
\hline Interval & Kriteria \\
\hline $0,000-0,199$ & Sangat Rendah \\
\hline $0,200-0,399$ & Rendah \\
\hline $0,400-0,599$ & Sedang \\
\hline $0,600-0,799$ & Kuat \\
\hline $0,800-0,999$ & Sangat Kuat \\
\hline \multicolumn{2}{|c|}{ Sumber: Sugiyono $(2017: 184)$} \\
\hline
\end{tabular}

\section{Koefisien Determinasi}

Menurut Ghozali (2016:95) mengatakan bahwa Koefisien determinasi $\left(R^{2}\right)$ pada intinya mengukur seberapa jauh kemampuan model dalam menerangkan variasi variabel dependen. Nilai koefisien determinasi adalah antara nol dan satu. Nilai $R^{2}$ yang kecil berarti kemampuan variabel-variabel independen dalam menjelaskan variasi variabel dependen amat 
terbatas. Nilai yang mendekati 1 berarti variabel-variabel independen memberikan hampir semua informasi yang dibutuhkan untuk memprediksi variasi variabel dependen.

\section{Uji Hipotesis Parsial}

Menurut Ghozali (2016:97) Uji statistik t pada dasarnya menunjukkan seberapa jauh pengaruh satu variabel independen secara individual terhadap variabel dependen. Prosedur yang dapat digunakan untuk penentuan hipotesis secara parsial adalah sebagai berikut:

1. Dalam penelitian ini digunakan tingkat signifikansi $(\alpha) 0,05$ dengan derajat kebebasan $(\mathrm{df}=$ $\mathrm{n}-\mathrm{k}$ ), dimana $\mathrm{n}$ adalah jumlah responden dan $\mathrm{k}$ adalah jumlah variabel.

2. Uji hipotesis yang diajukan, uji hipotesis nol $\left(H_{0}\right)$ dan hipotesis alternatif $\left(H_{a}\right)$ sebagai berikut:

$H_{0}: \beta 1=0$, Tidak terdapat pengaruh antara Electronic Word of Mouth terhadap keputusan berkunjung wisatawan di Desa Wisata Cibeusi.

$H_{a}: \beta 1 \neq 0$, Terdapat pengaruh antara Electronic Word of Mouth terhadap keputusan berkunjung wisatawan di Desa Wisata Cibeusi.

3. Kriteria keputusan yang digunakan adalah 0,05 , maka kriteria untuk penerimaan dan penolakan yang dipergunakan sebagai berikut:

1) Jika $T_{\text {hitung }}>T_{\text {tabel }}$ dan Nilai Sig $<0,05$ maka $H_{0}$ ditolak dan $H_{a}$ diterima. Artinya Electronic Word of Mouth berpengaruh terhadap keputusan berkunjung.

2) Jika $T_{\text {hitung }}<\mathrm{T}_{\text {tabel }}$ dan Nilai Sig $>0,05$ maka $H_{0}$ diterima dan $H_{a}$ ditolak. Artinya

Electronic Word of Mouth tidak berpengaruh terhadap keputusan berkunjung.

Berdasarkan situasi dan data awal penelitian, maka penulis dalam penelitian ini berangkat dari hipotesis bahwa terdapat pengaruh positif dan signifikan antara Electronic Word of Mouth dengan keputusan berkunjung.

\section{HASIL DAN PEMBAHASAN}

Dalam penelitian ini uji validitas menggunakan metode Pearson Product Moment. Untuk mengetahui apakah suatu instrumen penelitian dinyatakan valid, dilakukan dengan cara membandingkan $r_{\text {hiiiitung }}$ dengan $r_{\text {tabel }}$.

\section{Uji Validitas Electronic Word Of Mouth (X)}

Pengujian validitas variabel $e$-WOM terdiri dari 16 pernyataan, dimana seluruh $r_{\text {hiiiitung }}$ memiliki nilai lebih besar dari $r_{\text {tabel }}$, yaitu 0,30. Dengan demikian maka semua item pernyataan Electronic Word of Mouth valid dan dapat digunakan sebagai item dalam kuesioner.

\section{Uji Validitas Keputusan Berkunjung (Y)}

Pengujian validitas variabel keputusan berkunjung terdiri dari 11 pernyataan, dimana seluruh $r_{\text {hiiiitung }}$ memiliki nilai lebih besar dari $r_{\text {tabel }}$, yaitu 0,30 . Dengan demikian maka setiap instrumen variabel keputusan berkunjung valid dan dapat digunakan dalam pengambilan data.

\section{Hasil Uji Reliabilitas}

Uji reliabilitas digunakan untuk mengetahui sejauh mana konsistensi alat ukur, apakah hasilnya akan tetap konsisten apabila dilakukan pengukuran kembali. Kriteria uji reliabilitas dalam penelitian ini akan menggunakan teori menurut Nunnaly dalam Ghozali (2016:48) yang mengungkapkan suatu variabel dikatakan reliabel jika memiliki nilai cronbach's alpha $>0,70$. Pengujian realibilitas dalam penelitian ini akan menggunakan bantuan program komputer SPSS 26. Berikut hasil olah data pengujian reliabilitas: 


\section{Tabel 4}

\section{Hasil Uji Reliabilitas}

\begin{tabular}{|l|c|c|c|}
\hline \multicolumn{1}{|c|}{ Variabel } & $\begin{array}{c}r_{\text {inhhing }} \\
\text { Cronbach's } \\
\text { Alpha }\end{array}$ & $\begin{array}{c}r_{\text {tabel }} \\
\text { Cronbach's } \\
\text { Alpha }\end{array}$ & Keterangan \\
\hline Electronic Word Of Mouth & 0,858 & 0,70 & Reliabel \\
\hline Keputusan Berkunjung & 0,731 & 0,70 & Reliabel \\
\hline
\end{tabular}

Berdasarkan hasil uji reliabilitas menunjukkan bahwa kuesioner yang terdiri dari variabel Electronic Word of Mouth (X) dan keputusan berkunjung (Y) adalah reliabel karena memiliki nilai cronbach's alpha lebih besar dari 0,70. Dengan demikian, butir pernyataan dalam kuesioner memiliki konsistensi dalam mengukur, sehingga dapat digunakan dalam pengumpulan data selanjutnya.

\section{Hasil Analisis Deskriptif}

\section{Deskripsi Variabel Electronic Word Of Mouth}

Variabel independen yaitu Electronic Word of Mouth terdiri atas tujuh dimensi. Berikut uraian tabel untuk data deskripsi dari setiap dimensi penelitian:

Tabel 5

Tanggapan Mengenai Dimensi Platform Assistance

\begin{tabular}{|c|c|c|c|c|c|c|c|c|}
\hline \multirow{2}{*}{ Pernyataan } & \multicolumn{5}{|c|}{ Frekuensi } & \multirow[b]{2}{*}{$\begin{array}{c}\text { Total } \\
\text { Fi }\end{array}$} & \multirow{2}{*}{$\begin{array}{l}\text { Skor } \\
\text { Total }\end{array}$} & \multirow[b]{2}{*}{$\begin{array}{c}\text { Rata- } \\
\text { rata }\end{array}$} \\
\hline & $\begin{array}{c}1 \\
\text { (STS) }\end{array}$ & $\begin{array}{c}2 \\
\text { (TS) }\end{array}$ & $\begin{array}{c}3 \\
(\mathrm{RR})\end{array}$ & $\begin{array}{c}4 \\
(S)\end{array}$ & $\begin{array}{c}5 \\
(\mathrm{SS})\end{array}$ & & & \\
\hline \multirow{2}{*}{$\begin{array}{l}\text { Saya menyampaikan electronic } \\
\text { word of mouth dengan mudah } \\
\text { karena adanya internet }\end{array}$} & 0 & 5 & 18 & 55 & 22 & 100 & \multirow{2}{*}{394} & \multirow{2}{*}{3,94} \\
\hline & $0 \%$ & $2 \%$ & $14 \%$ & $56 \%$ & $28 \%$ & $100 \%$ & & \\
\hline \multirow{2}{*}{$\begin{array}{l}\text { Saya dapat bertukar informasi } \\
\text { dengan wisatawan lainnya } \\
\text { menggunakan jejaring sosial seperti } \\
W A, F B, I G \text { maupun forum seperti } \\
\text { google review }\end{array}$} & 0 & 4 & 6 & 61 & 29 & 100 & \multirow{2}{*}{415} & \multirow{2}{*}{4,15} \\
\hline & $0 \%$ & $2 \%$ & $4 \%$ & $59 \%$ & $35 \%$ & $100 \%$ & & \\
\hline \multicolumn{7}{|l|}{ Total dan Rata-rata Keseluruhan } & 809 & 4,04 \\
\hline
\end{tabular}

Berdasarkan dua pernyataan dari dimensi Platform Assistance diperoleh total skor sebesar 809 dengan rata-rata keseluruhan sebesar 4,04 yang berarti dikategorikan Baik. Dengan demikian Platform Assistance akan memberikan kemudahan dalam penyampaian $e$ WOM tentang Desa Wisata Cibeusi. 
Tabel 6

Tanggapan Mengenai Dimensi Venting Negative Feelings

\begin{tabular}{|c|c|c|c|c|c|c|c|c|}
\hline \multirow{2}{*}{ Pernyataan } & \multicolumn{5}{|c|}{ Frekuensi } & \multirow[b]{2}{*}{$\begin{array}{c}\text { Total } \\
\text { Fi }\end{array}$} & \multirow[b]{2}{*}{$\begin{array}{l}\text { Skor } \\
\text { Total }\end{array}$} & \multirow[b]{2}{*}{$\begin{array}{l}\text { Rata } \\
\text {-rata }\end{array}$} \\
\hline & $\begin{array}{c}1 \\
\text { (STS) }\end{array}$ & $\begin{array}{c}2 \\
\text { (TS) }\end{array}$ & $\begin{array}{c}3 \\
\text { (RR) }\end{array}$ & $\begin{array}{c}4 \\
\text { (S) }\end{array}$ & $\begin{array}{c}5 \\
(\mathbf{S S})\end{array}$ & & & \\
\hline \multirow{2}{*}{$\begin{array}{l}\text { Melalui } e-W O M \text {, saya bisa } \\
\text { mendapatkan informasi negatif } \\
\text { tentang Desa Wisata Cibeusi }\end{array}$} & 4 & 15 & 30 & 46 & 5 & 100 & \multirow{2}{*}{333} & \multirow{2}{*}{3,33} \\
\hline & $1 \%$ & $9 \%$ & $27 \%$ & $55 \%$ & $8 \%$ & $100 \%$ & & \\
\hline \multirow{2}{*}{$\begin{array}{l}\text { Melalui } e-W O M \text {, saya dapat } \\
\text { merasakan ketidakpuasan } \\
\text { wisatawan lain yang pernah } \\
\text { berkunjung }\end{array}$} & 3 & 18 & 25 & 46 & 8 & 100 & \multirow[t]{2}{*}{338} & \multirow[t]{2}{*}{3,38} \\
\hline & $1 \%$ & $11 \%$ & $22 \%$ & $54 \%$ & $12 \%$ & $100 \%$ & & \\
\hline \multicolumn{7}{|l|}{ Total dan Rata-rata Keseluruhan } & 671 & 3,35 \\
\hline
\end{tabular}

Berdasarkan dua pernyataan dari dimensi Venting Negative Feelings diperoleh total skor sebesar 671 dengan rata-rata keseluruhan sebesar 3,35 yang berarti dikategorikan Cukup. Dengan demikian, responden dalam penelitian ini ragu-ragu bahwa mereka bisa mendapatkan informasi negatif tentang Desa Wisata Cibeusi melalui e-WOM.

Tabel 7

Tanggapan Mengenai Dimensi Concern for Other Consumers

\begin{tabular}{|c|c|c|c|c|c|c|c|c|}
\hline \multirow{2}{*}{ Pernyataan } & \multicolumn{5}{|c|}{ Frekuensi } & \multirow{2}{*}{$\begin{array}{c}\text { Total } \\
\text { Fi }\end{array}$} & \multirow{2}{*}{$\begin{array}{l}\text { Skor } \\
\text { Total }\end{array}$} & \multirow{2}{*}{$\begin{array}{l}\text { Rata } \\
\text {-rata }\end{array}$} \\
\hline & $\begin{array}{c}1 \\
\text { (STS) }\end{array}$ & $\begin{array}{c}2 \\
\text { (TS) }\end{array}$ & $\begin{array}{c}3 \\
(\mathbf{R R})\end{array}$ & $\begin{array}{c}4 \\
(\mathbf{S})\end{array}$ & $\begin{array}{c}5 \\
(\mathbf{S S})\end{array}$ & & & \\
\hline \multirow{2}{*}{$\begin{array}{l}\text { Saya mendapat rekomendasi tentang } \\
\text { Desa Wisata Cibeusi melalui } e-W O M\end{array}$} & 1 & 4 & 17 & 56 & 22 & 100 & \multirow{2}{*}{394} & \multirow{2}{*}{3,94} \\
\hline & $0 \%$ & $2 \%$ & $13 \%$ & $57 \%$ & $28 \%$ & $100 \%$ & & \\
\hline \multirow{2}{*}{$\begin{array}{l}\text { Dengan } e-W O M \text {, saya merasakan } \\
\text { kepedulian dan ketulusan wisatawan } \\
\text { lain saat mereka merekomendasikan } \\
\text { Desa Wisata Cibeusi }\end{array}$} & 0 & 3 & 18 & 59 & 20 & 100 & \multirow[b]{2}{*}{396} & \multirow[b]{2}{*}{3,96} \\
\hline & $0 \%$ & $1 \%$ & $14 \%$ & $60 \%$ & $25 \%$ & $100 \%$ & & \\
\hline \multirow{2}{*}{$\begin{array}{l}\text { Saya merekomendasikan ulang Desa } \\
\text { Wisata Cibeusi ke orang lain dengan } \\
\text { melakukan } e-W O M\end{array}$} & 0 & 2 & 7 & 62 & 29 & 100 & \multirow{2}{*}{418} & \multirow{2}{*}{4,18} \\
\hline & $0 \%$ & $1 \%$ & $5 \%$ & $59 \%$ & $35 \%$ & $100 \%$ & & \\
\hline \multicolumn{7}{|l|}{ Total dan Rata-rata Keseluruhan } & 1.208 & 4,03 \\
\hline
\end{tabular}

Berdasarkan tiga pernyataan dari dimensi Concern for Other Consumers diperoleh total skor sebesar 1.208 dengan rata-rata keseluruhan sebesar 4,03 yang dikategorikan berarti Baik. 
Tabel 8

Tanggapan Dimensi Extraversion/positive self-enchanment

\begin{tabular}{|c|c|c|c|c|c|c|c|c|}
\hline \multirow{2}{*}{ Pernyataan } & \multicolumn{5}{|c|}{ Frekuensi } & \multirow{2}{*}{$\begin{array}{c}\text { Total } \\
\text { Fi }\end{array}$} & \multirow{2}{*}{$\begin{array}{l}\text { Skor } \\
\text { Total }\end{array}$} & \multirow{2}{*}{$\begin{array}{l}\text { Rata } \\
\text {-rata }\end{array}$} \\
\hline & $\begin{array}{c}1 \\
\text { (STS) }\end{array}$ & $\begin{array}{c}2 \\
\text { (TS) }\end{array}$ & $\begin{array}{c}3 \\
\text { (RR) }\end{array}$ & $\begin{array}{c}4 \\
(S)\end{array}$ & $\begin{array}{c}5 \\
(\mathrm{SS})\end{array}$ & & & \\
\hline \multirow{2}{*}{$\begin{array}{l}\text { Melalui } e-W O M \text {, saya dapat } \\
\text { merasakan kebahagiaan orang lain } \\
\text { yang sudah berkunjung ke Desa } \\
\text { Wisata Cibeusi }\end{array}$} & 0 & 5 & 21 & 50 & 24 & 100 & \multirow{2}{*}{393} & \multirow{2}{*}{3,93} \\
\hline & $0 \%$ & $2 \%$ & $16 \%$ & $51 \%$ & $31 \%$ & $100 \%$ & & \\
\hline \multirow{2}{*}{$\begin{array}{l}\text { Dengan } e-W O M \text {, saya dapat } \\
\text { memberi informasi positif kepada } \\
\text { orang lain }\end{array}$} & 0 & 1 & 12 & 60 & 27 & 100 & \multirow{2}{*}{413} & \multirow{2}{*}{4,13} \\
\hline & $0 \%$ & $0 \%$ & $9 \%$ & $58 \%$ & $33 \%$ & $100 \%$ & & \\
\hline \multicolumn{7}{|l|}{ Total dan Rata-rata Keseluruhan } & 806 & 4,03 \\
\hline
\end{tabular}

Berdasarkan dua pernyataan dari Extraversion/positive self-enchanment diperoleh total skor sebesar 806 dengan rata-rata keseluruhan sebesar 4,03 yang berarti dikategorikan Baik.

Tabel 9

Tanggapan Mengenai Dimensi Social Benefits

\begin{tabular}{|c|c|c|c|c|c|c|c|c|}
\hline \multirow{2}{*}{ Pernyataan } & \multicolumn{5}{|c|}{ Frekuensi } & \multirow{2}{*}{$\begin{array}{c}\text { Total } \\
\text { Fi }\end{array}$} & \multirow{2}{*}{$\begin{array}{l}\text { Skor } \\
\text { Total }\end{array}$} & \multirow{2}{*}{$\begin{array}{r}\text { Rata- } \\
\text { rata }\end{array}$} \\
\hline & $\begin{array}{c}1 \\
\text { (STS) }\end{array}$ & $\begin{array}{c}2 \\
\text { (TS) }\end{array}$ & $\begin{array}{c}3 \\
(R R)\end{array}$ & $\begin{array}{c}4 \\
(S)\end{array}$ & $\begin{array}{c}5 \\
(\mathrm{SS})\end{array}$ & & & \\
\hline \multirow{2}{*}{$\begin{array}{l}\text { Saya melakukan } e-W O M \text { karena } \\
\text { ingin berbagi informasi dengan } \\
\text { orang lain }\end{array}$} & 0 & 4 & 18 & 56 & 22 & 100 & \multirow{2}{*}{396} & \multirow{2}{*}{3,96} \\
\hline & $0 \%$ & $2 \%$ & $14 \%$ & $56 \%$ & $28 \%$ & $100 \%$ & & \\
\hline \multirow{2}{*}{$\begin{array}{l}\text { Saya melakukan } e-W O M \text { karena } \\
\text { keinginan berinteraksi di } \\
\text { lingkungan jejaring sosial }\end{array}$} & 0 & 3 & 20 & 47 & 30 & 100 & \multirow[b]{2}{*}{404} & \multirow[b]{2}{*}{4,04} \\
\hline & $0 \%$ & $2 \%$ & $15 \%$ & $46 \%$ & $37 \%$ & $100 \%$ & & \\
\hline \multicolumn{7}{|l|}{ Total dan Rata-rata Keseluruhan } & 800 & 4,00 \\
\hline
\end{tabular}

Berdasarkan dua pernyataan dari dimensi Social Benefits diperoleh total skor sebesar 800 dengan rata-rata keseluruhan sebesar 4,00 yang berarti dikategorikan Baik. 
Tabel 10

Tanggapan Mengenai Dimensi Helping The Company

\begin{tabular}{|c|c|c|c|c|c|c|c|c|}
\hline \multirow{2}{*}{ Pernyataan } & \multicolumn{5}{|c|}{ Frekuensi } & \multirow{2}{*}{$\begin{array}{c}\text { Total } \\
\text { Fi }\end{array}$} & \multirow{2}{*}{$\begin{array}{l}\text { Skor } \\
\text { Total }\end{array}$} & \multirow{2}{*}{$\begin{array}{c}\text { Rata- } \\
\text { rata }\end{array}$} \\
\hline & $\begin{array}{c}1 \\
(\mathrm{STS})\end{array}$ & $\begin{array}{c}2 \\
(S)\end{array}$ & $\begin{array}{c}3 \\
\text { (RR) }\end{array}$ & $\begin{array}{c}4 \\
(\mathrm{SS})\end{array}$ & $\begin{array}{c}5 \\
(\mathrm{SS})\end{array}$ & & & \\
\hline \multirow{2}{*}{$\begin{array}{l}\text { Dengan melakukan } e-W O M \text { saya } \\
\text { dapat membantu mempromosikan } \\
\text { tentang Desa Wisata Cibeusi }\end{array}$} & 0 & 1 & 17 & 59 & 23 & 100 & \multirow{2}{*}{404} & \multirow{2}{*}{4,04} \\
\hline & $0 \%$ & $1 \%$ & $13 \%$ & $58 \%$ & $28 \%$ & $100 \%$ & & \\
\hline \multirow{2}{*}{$\begin{array}{l}\text { Dengan melakukan } e-W O M \text {, saya } \\
\text { dapat membantu mempublikasikan } \\
\text { Desa Wisata Cibeusi }\end{array}$} & 0 & 3 & 9 & 62 & 26 & 100 & \multirow{2}{*}{411} & \multirow{2}{*}{4,11} \\
\hline & $0 \%$ & $1 \%$ & $7 \%$ & $60 \%$ & $32 \%$ & $100 \%$ & & \\
\hline \multirow{2}{*}{$\begin{array}{l}\text { Dengan } e-W O M \text { saya dapat } \\
\text { membantu meningkatkan kunjungan } \\
\text { ke Desa Wisata Cibeusi }\end{array}$} & 0 & 4 & 16 & 58 & 22 & 100 & \multirow{2}{*}{398} & \multirow{2}{*}{3,98} \\
\hline & $0 \%$ & $2 \%$ & $12 \%$ & $58 \%$ & $28 \%$ & $100 \%$ & & \\
\hline \multicolumn{7}{|l|}{ Total dan Rata-rata Keseluruhan } & 1.213 & 4,04 \\
\hline
\end{tabular}

Berdasarkan tiga pernyataan dari dimensi Helping The Company diperoleh total skor sebesar 1.213 dengan rata-rata keseluruhan sebesar 4,04 yang berarti Baik.

Tabel 11

Tanggapan Mengenai Dimensi Advice Seeking

\begin{tabular}{|c|c|c|c|c|c|c|c|c|}
\hline \multirow{2}{*}{ Pernyataan } & \multicolumn{5}{|c|}{ Frekuensi } & \multirow{2}{*}{$\begin{array}{c}\text { Total } \\
\text { Fi }\end{array}$} & \multirow{2}{*}{$\begin{array}{l}\text { Skor } \\
\text { Total }\end{array}$} & \multirow{2}{*}{$\begin{array}{c}\text { Rata- } \\
\text { rata }\end{array}$} \\
\hline & $\begin{array}{c}1 \\
(\mathrm{STS})\end{array}$ & $\begin{array}{c}2 \\
\text { (TS) }\end{array}$ & $\begin{array}{c}3 \\
\text { (RR) }\end{array}$ & $\begin{array}{c}4 \\
(\mathrm{~S})\end{array}$ & $\begin{array}{c}5 \\
(\mathrm{SS})\end{array}$ & & & \\
\hline \multirow{2}{*}{$\begin{array}{l}\text { Saya mencari dan menerima saran } \\
\text { tentang Desa Wisata Cibeusi melalui } \\
\text { internet }\end{array}$} & 2 & 8 & 19 & 56 & 15 & 100 & \multirow{2}{*}{374} & \multirow[b]{2}{*}{3,74} \\
\hline & $1 \%$ & $4 \%$ & $15 \%$ & $60 \%$ & $20 \%$ & $100 \%$ & & \\
\hline \multirow{2}{*}{$\begin{array}{l}\text { Saya menerima informasi } \\
\text { keunggulan daya tarik Desa Wisata } \\
\text { Cibeusi melalui internet }\end{array}$} & 0 & 1 & 17 & 63 & 19 & 100 & \multirow{2}{*}{400} & \multirow[b]{2}{*}{4,00} \\
\hline & $0 \%$ & $0 \%$ & $13 \%$ & $63 \%$ & $24 \%$ & $100 \%$ & & \\
\hline \multicolumn{7}{|l|}{ Total dan Rata-rata Keseluruhan } & 774 & 3,87 \\
\hline
\end{tabular}

Berdasarkan dua pernyataan dari dimensi Advice Seeking diperoleh total skor sebesar 774 dengan rata-rata keseluruhan sebesar 3,87 yang berarti dikategorikan Baik. Berdasarkan hasil keseluruhan diatas maka, rata-rata terbesar diperoleh dari dimensi Platform Assistance dan Helping The Company dengan rata-rata sebesar 4,04 yang dikategorikan Baik. Sedangkan ratarata terendah diperoleh dari dimensi Venting Negative Feelings dengan rata-rata sebesar 3,35 yang dikategorikan Cukup. 


\section{Deskripsi Variabel Keputusan Berkunjung}

Dalam penelitian ini variabel dependen yaitu keputusan berkunjung terdiri atas enam dimensi dan sebelas pernyataan.

Tabel 12

Tanggapan Mengenai Dimensi Pemilihan Produk

\begin{tabular}{|c|c|c|c|c|c|c|c|c|}
\hline \multirow{2}{*}{ Pernyataan } & \multicolumn{5}{|c|}{ Frekuensi } & \multirow{2}{*}{$\begin{array}{c}\text { Total } \\
\text { Fi }\end{array}$} & \multirow{2}{*}{$\begin{array}{l}\text { Skor } \\
\text { Total }\end{array}$} & \multirow{2}{*}{$\begin{array}{l}\text { Rata } \\
\text {-rata }\end{array}$} \\
\hline & $\begin{array}{c}1 \\
\text { (STS) }\end{array}$ & $\begin{array}{c}2 \\
\text { (TS) }\end{array}$ & $\begin{array}{c}3 \\
\text { (RR) }\end{array}$ & $\begin{array}{c}4 \\
\text { (S) }\end{array}$ & $\begin{array}{c}5 \\
(\mathrm{SS})\end{array}$ & & & \\
\hline \multirow{2}{*}{$\begin{array}{l}\text { Saya memilih Desa Wisata Cibeusi } \\
\text { karena memiliki beragam daya tarik } \\
\text { wisata }\end{array}$} & 0 & 2 & 17 & 57 & 24 & 100 & \multirow{2}{*}{403} & \multirow{2}{*}{4,03} \\
\hline & $0 \%$ & $1 \%$ & $13 \%$ & $56 \%$ & $30 \%$ & $100 \%$ & & \\
\hline \multirow{2}{*}{$\begin{array}{l}\text { Saya lebih memilih Desa Wisata } \\
\text { Cibeusi sebagai tujuan wisata } \\
\text { dibandingkan Desa Wisata lainnya } \\
\text { yang ada di Kabupaten Subang }\end{array}$} & 0 & 7 & 20 & 59 & 14 & 100 & \multirow[b]{2}{*}{380} & \multirow[b]{2}{*}{3,80} \\
\hline & $0 \%$ & $4 \%$ & $16 \%$ & $62 \%$ & $18 \%$ & $100 \%$ & & \\
\hline \multicolumn{7}{|l|}{ Total dan Rata-rata Keseluruhan } & 783 & 3,91 \\
\hline
\end{tabular}

Berdasarkan dua pernyataan dari dimensi pemilihan produk diperoleh total skor sebesar

783 dengan rata-rata keseluruhan sebesar 3,91 yang berarti dikategorikan Baik

Tabel 13

Tanggapan Mengenai Dimensi Pemilihan Brand

\begin{tabular}{|c|c|c|c|c|c|c|c|c|}
\hline \multirow{2}{*}{ Pernyataan } & \multicolumn{5}{|c|}{ Frekuensi } & \multirow{2}{*}{$\begin{array}{l}\text { Total } \\
\text { Fi }\end{array}$} & \multirow{2}{*}{$\begin{array}{l}\text { Skor } \\
\text { Total }\end{array}$} & \multirow{2}{*}{$\begin{array}{l}\text { Rata } \\
\text {-rata }\end{array}$} \\
\hline & $\begin{array}{c}1 \\
(\mathrm{STS})\end{array}$ & $\begin{array}{c}2 \\
(\mathrm{TS})\end{array}$ & $\begin{array}{c}3 \\
(\mathbf{R R})\end{array}$ & $\begin{array}{c}4 \\
(\mathbf{S})\end{array}$ & $\begin{array}{c}5 \\
(\mathbf{S S})\end{array}$ & & & \\
\hline \multirow{2}{*}{$\begin{array}{l}\text { Saya berkunjung ke Desa Wisata } \\
\text { Cibeusi karena keinginan melepas } \\
\text { penat dari kegiatan sehari-hari }\end{array}$} & 1 & 1 & 6 & 44 & 48 & 100 & \multirow{2}{*}{437} & \multirow[b]{2}{*}{4,37} \\
\hline & $0 \%$ & $1 \%$ & $4 \%$ & $40 \%$ & $55 \%$ & $100 \%$ & & \\
\hline \multirow{2}{*}{$\begin{array}{l}\text { Saya berkunjung karena popularitas } \\
\text { Desa Wisata Cibeusi sangat baik }\end{array}$} & 0 & 3 & 21 & 64 & 12 & 100 & \multirow{2}{*}{385} & \multirow{2}{*}{3,85} \\
\hline & $0 \%$ & $2 \%$ & $16 \%$ & $66 \%$ & $16 \%$ & $100 \%$ & & \\
\hline \multicolumn{7}{|l|}{ Total dan Rata-rata Keseluruhan } & 822 & 4,11 \\
\hline
\end{tabular}

Berdasarkan dua pernyataan dari dimensi pemilihan Brand diperoleh total skor sebesar 822 dengan rata-rata keseluruhan sebesar 4,11 yang berarti dikategorikan Baik. 
Tabel 14

Tanggapan Mengenai Dimensi Jumlah Pembelian

\begin{tabular}{|c|c|c|c|c|c|c|c|c|}
\hline \multirow{2}{*}{ Pernyataan } & \multicolumn{5}{|c|}{ Frekuensi } & \multirow{2}{*}{$\begin{array}{l}\text { Total } \\
\text { Fi }\end{array}$} & \multirow{2}{*}{$\begin{array}{l}\text { Skor } \\
\text { Total }\end{array}$} & \multirow{2}{*}{$\begin{array}{l}\text { Rata } \\
\text {-rata }\end{array}$} \\
\hline & $\begin{array}{c}1 \\
\text { (STS) }\end{array}$ & $\begin{array}{c}2 \\
\text { (TS) }\end{array}$ & $\begin{array}{c}3 \\
\text { (RR) }\end{array}$ & $\begin{array}{c}4 \\
\text { (S) }\end{array}$ & $\begin{array}{c}5 \\
\text { (SS) }\end{array}$ & & & \\
\hline \multirow{2}{*}{$\begin{array}{l}\text { Saya akan mengunjungi kembali } \\
\text { Desa Wisata Cibeusi di lain waktu }\end{array}$} & 1 & 0 & 21 & 55 & 23 & 100 & \multirow{2}{*}{399} & \multirow{2}{*}{3,99} \\
\hline & $0 \%$ & $0 \%$ & $16 \%$ & $55 \%$ & $29 \%$ & $100 \%$ & & \\
\hline \multirow{2}{*}{$\begin{array}{l}\text { Ketika sedang berada disini saya } \\
\text { bisa menghabiskan waktu lebih } \\
\text { dari satu jam }\end{array}$} & 1 & 1 & 7 & 48 & 47 & 100 & \multirow{2}{*}{431} & \multirow{2}{*}{4,31} \\
\hline & $0 \%$ & $0 \%$ & $5 \%$ & $44 \%$ & $51 \%$ & $100 \%$ & & \\
\hline \multicolumn{7}{|l|}{ Total dan Rata-rata Keseluruhan } & 830 & 4,15 \\
\hline
\end{tabular}

Berdasarkan dua pernyataan dari dimensi jumlah pembelian diperoleh total skor sebesar 830 dengan rata-rata keseluruhan sebesar 4,15 yang berarti dikategorikan Baik. Berikut interprestasi dimensi ini ke dalam garis kontinum:

Tabel 15

Tanggapan Mengenai Dimensi Pemilihan Penyalur

\begin{tabular}{|c|c|c|c|c|c|c|c|c|}
\hline \multirow{2}{*}{ Pernyataan } & \multicolumn{5}{|c|}{ Frekuensi } & \multirow{2}{*}{$\begin{array}{c}\text { Total } \\
\text { Fi }\end{array}$} & \multirow{2}{*}{$\begin{array}{l}\text { Skor } \\
\text { Total }\end{array}$} & \multirow{2}{*}{$\begin{array}{c}\text { Rata- } \\
\text { rata }\end{array}$} \\
\hline & $\begin{array}{c}1 \\
\text { (STS) }\end{array}$ & $\begin{array}{c}2 \\
\text { (TS) }\end{array}$ & $\begin{array}{c}3 \\
\text { (RR) }\end{array}$ & $\begin{array}{c}4 \\
(S)\end{array}$ & $\begin{array}{c}5 \\
(\mathrm{SS})\end{array}$ & & & \\
\hline \multirow{2}{*}{$\begin{array}{l}\text { Saya memutuskan tidak } \\
\text { menggunakan penyalur seperti agen } \\
\text { perjalanan karena harga yang } \\
\text { ditawarkan oleh setiap daya tarik } \\
\text { Desa Wisata Cibeusi murah }\end{array}$} & 1 & 4 & 14 & 39 & 42 & 100 & \multirow[b]{2}{*}{417} & \multirow[b]{2}{*}{4,17} \\
\hline & $0 \%$ & $2 \%$ & $11 \%$ & $37 \%$ & $50 \%$ & $100 \%$ & & \\
\hline \multirow{2}{*}{$\begin{array}{l}\text { Saya dapat menggunakan jasa } \\
\text { seperti agen perjalanan untuk } \\
\text { berkunjung ke Desa Wisata Cibeusi }\end{array}$} & 1 & 10 & 37 & 41 & 11 & 100 & \multirow{2}{*}{351} & \multirow[b]{2}{*}{3,51} \\
\hline & $0 \%$ & $5 \%$ & $32 \%$ & $47 \%$ & $16 \%$ & $100 \%$ & & \\
\hline \multicolumn{7}{|l|}{ Total dan Rata-rata Keseluruhan } & 768 & 3,84 \\
\hline
\end{tabular}

Berdasarkan dua pernyataan dari dimensi pemilihan penyalur diperoleh total skor sebesar 768 dengan rata-rata keseluruhan sebesar 3,84 yang berarti dikategorikan Baik. 
Tabel 16

Tanggapan Mengenai Dimensi Penentuan Waktu Kunjungan

\begin{tabular}{|c|c|c|c|c|c|c|c|c|}
\hline \multirow{2}{*}{ Pernyataan } & \multicolumn{5}{|c|}{ Frekuensi } & \multirow{2}{*}{$\begin{array}{c}\text { Total } \\
\text { Fi }\end{array}$} & \multirow{2}{*}{$\begin{array}{l}\text { Skor } \\
\text { Total }\end{array}$} & \multirow{2}{*}{$\begin{array}{c}\text { Rata- } \\
\text { rata }\end{array}$} \\
\hline & $\begin{array}{c}1 \\
(\mathrm{STS})\end{array}$ & $\begin{array}{c}2 \\
\text { (TS) }\end{array}$ & $\begin{array}{c}3 \\
\text { (RR) }\end{array}$ & $\begin{array}{c}4 \\
(\mathrm{~S})\end{array}$ & $\begin{array}{c}5 \\
(\mathrm{SS})\end{array}$ & & & \\
\hline \multirow{2}{*}{$\begin{array}{l}\text { Saya dapat berkunjung ke Desa } \\
\text { Wisata Cibeusi kapan saja apabila } \\
\text { ada waktu luang }\end{array}$} & 0 & 4 & 10 & 57 & 29 & 100 & \multirow{2}{*}{411} & \multirow[b]{2}{*}{4,11} \\
\hline & $0 \%$ & $2 \%$ & $7 \%$ & $55 \%$ & $36 \%$ & $100 \%$ & & \\
\hline \multirow{2}{*}{$\begin{array}{l}\text { Saya memutuskan berkunjung ke } \\
\text { Desa Wisata Cibeusi ketika sedang } \\
\text { hari libur }\end{array}$} & 0 & 1 & 14 & 50 & 35 & 100 & \multirow[b]{2}{*}{419} & \multirow[b]{2}{*}{4,19} \\
\hline & $0 \%$ & $0 \%$ & $10 \%$ & $48 \%$ & $42 \%$ & $100 \%$ & & \\
\hline \multicolumn{7}{|l|}{ Total dan Rata-rata Keseluruhan } & 830 & 4,15 \\
\hline
\end{tabular}

Berdasarkan dua pernyataan dari dimensi penentuan waktu kunjungan diperoleh total skor sebesar 830 dengan rata-rata keseluruhan sebesar 4,15 yang berarti dikategorikan Baik.

Tabel 17

Tanggapan Mengenai Dimensi Metode Pembayaran

\begin{tabular}{|c|c|c|c|c|c|c|c|c|}
\hline \multirow{2}{*}{ Pernyataan } & \multicolumn{5}{|c|}{ Frekuensi } & \multirow{2}{*}{$\begin{array}{c}\text { Total } \\
\text { Fi }\end{array}$} & \multirow{2}{*}{$\begin{array}{l}\text { Skor } \\
\text { Total }\end{array}$} & \multirow{2}{*}{$\begin{array}{r}\text { Rata- } \\
\text { rata }\end{array}$} \\
\hline & $\begin{array}{c}1 \\
(\mathrm{STS})\end{array}$ & $\begin{array}{c}2 \\
(\mathrm{TS})\end{array}$ & $\begin{array}{c}3 \\
(\mathbf{R R})\end{array}$ & $\begin{array}{c}4 \\
(\mathrm{~S})\end{array}$ & $\begin{array}{c}5 \\
(\mathbf{S S})\end{array}$ & & & \\
\hline \multirow{2}{*}{$\begin{array}{l}\text { Saya menggunakan uang tunai } \\
\text { ketika membayar }\end{array}$} & 0 & 3 & 11 & 58 & 28 & 100 & \multirow{2}{*}{411} & \multirow{2}{*}{4,11} \\
\hline & $0 \%$ & $2 \%$ & $8 \%$ & $56 \%$ & $34 \%$ & $100 \%$ & & \\
\hline \multicolumn{7}{|c|}{ Total dan Rata-rata Keseluruhan } & 411 & 4,11 \\
\hline
\end{tabular}

Skor total dari 100 responden mengenai pernyataan pertama dari dimensi jumlah pembelian ini sebesar 411 dengan rata-rata 4,11 yang berarti responden Setuju dan dikategorikan Baik. Hal ini dikarenakan, di setiap daya tarik Desa Wisata Cibeusi untuk pembayaran hanya dilakukan dengan menggunakan uang tunai. Berdasarkan hasil keseluruhan dimensi diatas maka, rata-rata terbesar diperoleh dari dimensi Jumlah Pembelian dan Penentuan Waktu Kunjungan dengan rata-rata 4,04 dikategorikan Baik. Sedangkan rata-rata terendah dari dimensi Pemilihan Penyalur dengan rata-rata 3,84 yang dikategorikan Baik.

Tabel 18

Kesimpulan Analisis Deskriptif

\begin{tabular}{|c|c|c|c|c|c|}
\hline Variabel & N & Item Pernyataan & Total Skor & Rata-Rata & Kategori \\
\hline Electronic Word of Mouth $(\mathrm{X})$ & 100 & 16 & 6281 & 3,92 & Baik \\
\hline
\end{tabular}




\begin{tabular}{|l|l|l|l|l|l|}
\hline Keputusan Berkunjung (Y) & 100 & 11 & 4444 & 4,04 & Baik \\
\hline
\end{tabular}

Pada tabel 18 ditunjukkan bahwa rata-rata keseluruhan dari 16 pernyataan variabel independen yaitu Electronic Word of Mouth sebesar 3,92 dan dikaterogikan Baik. Sedangkan rata-rata keseluruhan dari 11 pernyataan variabel dependen yaitu keputusan berkunjung sebesar 4,04 dan berada dalam kategori Baik.

\section{Analisis Verifikatif}

\section{Hasil Uji Normalitas}

Pengujian normalitas menggunakan One Sample Kolmogorov Smirnov dengan ketentuan apabila nilai signifikansi $>0,05$, maka data terdistribusi normal. Sedangkan jika nilai signifikansi $<0,05$, maka data tidak terdistribusi normal. Berikut hasil pengujian normalitas dengan pengunaan program SPSS:

Tabel 19

Uji Kolmogorov Smirnov

\begin{tabular}{|l|l|r|}
\hline \multicolumn{2}{|c|}{ One-Sample Kolmogorov-Smirnov Test } \\
\hline \multirow{2}{|c|}{} & $\begin{array}{l}\text { Unstandardized } \\
\text { Residual }\end{array}$ \\
\hline \multirow{2}{*}{$N$} & 100 \\
\hline \multirow{2}{*}{ Normal Parameters ${ }^{a, b}$} & Mean &, 0000000 \\
\cline { 2 - 4 } & $\begin{array}{l}\text { Std. } \\
\text { Deviation }\end{array}$ & 4,63558009 \\
\hline \multirow{2}{*}{$\begin{array}{l}\text { Most Extreme } \\
\text { Differences }\end{array}$} & Absolute &, 058 \\
\cline { 2 - 4 } & Positive &, 058 \\
\cline { 2 - 3 } & Negative &,- 048 \\
\hline Test Statistic & &, 058 \\
\hline Asymp. Sig. (2-tailed) & &, $200^{\mathrm{c}, \mathrm{d}}$ \\
\hline
\end{tabular}

Berdasarkan tabel 19 hasil uji metode Kolmogorov Smirnov sebesar 0,058 dengan Asymp. Sig. (2-tailed) atau nilai signifikansi sebesar 0,200. Dapat disimpulkan hasil uji normalitas dalam penelitian ini didapatkan nilai signifikansi sebesar $0,200>0,05$, hal ini menunjukkan bahwa data yang diuji dalam penelitian ini terdistribusi secara normal.

\section{Hasil Regresi Linier Sederhana}

Menggunakan model regresi linier sederhana yaitu untuk mengetahui pengaruh antara satu variabel independen terhadap variabel dependen. Berikut hasil olah data analisis regresi linier sederhana: 
Tabel 20

Hasil Uji Regresi Linier Sederhana

\section{Coefficients $^{\mathrm{a}}$}

\begin{tabular}{|c|c|c|c|c|c|c|}
\hline \multirow{2}{*}{\multicolumn{2}{|c|}{ Model }} & \multicolumn{2}{|c|}{$\begin{array}{l}\text { Unstandardized } \\
\text { Coefficients }\end{array}$} & \multirow{2}{*}{$\begin{array}{c}\text { Standardized } \\
\text { Coefficients } \\
\text { Beta }\end{array}$} & \multirow[b]{2}{*}{$\mathrm{t}$} & \multirow[b]{2}{*}{ Sig. } \\
\hline & & $B$ & Std. Error & & & \\
\hline 1 & (Constant) & 21,577 & 3,019 & & 7,146 &, 000 \\
\hline & Electronic Word of Mouth & ,308 &, 056 & ,486 & 5,512 &, 000 \\
\hline
\end{tabular}

a. Dependent Variable: Keputusan Berkunjung

Berdasarkan tabel 20, nilai koefisien regresi terdapat pada kolom unstandardized coefficients dalam kolom B, dengan nilai konstanta sebesar 21,577, sedangkan nilai koefisien regresi Electronic Word of Mouth sebesar 0,308. Maka persamaan model regresinya adalah sebagai berikut:

$$
\begin{aligned}
& \mathrm{Y}=\alpha+\mathrm{bX} \\
& \mathrm{Y}=21,577+0,308 \mathrm{X}
\end{aligned}
$$

Keterangan : $\mathrm{Y}=$ Nilai yang diprediksikan, $\alpha=$ Konstanta, $\mathrm{b}=$ Koefisien regresi, $\mathrm{X}=$ Nilai variabel independen

Dapat dijelaskan model regresi diatas yaitu konstanta 21,577 menyatakan jika variabel Electronic Word of Mouth memiliki nilai konstan atau 0, maka besarnya nilai keputusan berkunjung yaitu 21,577. Sedangkan koefisien regresi variabel Electronic Word of Mouth sebesar 0,308 dapat diartikan apabila Electronic Word of Mouth meningkat 1 satuan, maka nilai keputusan berkunjung meningkat sebesar 0,308. Berdasarkan data responden sebanyak 100 responden yang diperoleh dari wisatawan yang berkunjung ke Desa Wisata Cibeusi, maka keputusan berkunjung adalah : $21,577+(0,308 \times 100)=21,577+30,8=52,377$. Sehingga dapat diperkirakan keputusan berkunjung wisatawan dalam penelitian ini sebesar 52,377.

\section{Hasil Analisis Korelasi}

Analisis korelasi digunakan untuk mengetahui keeratan hubungan antara variabel electronic word of mouth dengan keputusan berkunjung. Berikut hasil olah data koefisien korelasi:

Tabel 21

Hasil Koefisien Korelasi

\begin{tabular}{|c|c|c|c|}
\hline & & $\begin{array}{c}\text { Electronic } \\
\text { Word of } \\
\text { Mouth }\end{array}$ & $\begin{array}{c}\text { Keputusan } \\
\text { Berkunjun } \\
\quad \mathrm{g}\end{array}$ \\
\hline $\begin{array}{l}\text { Electronic Word of } \\
\text { Mouth }\end{array}$ & $\begin{array}{l}\text { Pearson } \\
\text { Correlation }\end{array}$ & 1 &, $486^{* *}$ \\
\hline
\end{tabular}

Correlations 


\begin{tabular}{|c|c|c|c|}
\hline & Sig. (2-tailed) & &, 000 \\
\hline & $N$ & 100 & 100 \\
\hline \multirow[t]{3}{*}{$\begin{array}{l}\text { Keputusan } \\
\text { Berkunjung }\end{array}$} & $\begin{array}{l}\text { Pearson } \\
\text { Correlation }\end{array}$ &, $486^{* *}$ & 1 \\
\hline & Sig. (2-tailed) &, 000 & \\
\hline & $N$ & 100 & 100 \\
\hline
\end{tabular}

Koefisien korelasi yang ditemukan sebesar 0,486 dengan signifikansi korelasi di level 0,01 (2tailed). Maka dapat disimpulkan dalam penelitian ini hubungan korelasi antara variabel Electronic Word of Mouth dengan keputusan berkunjung termasuk pada kategori sedang karena berada pada rentang $0,400-0,599$.

\section{Hasil Koefisien Determinasi}

Koefisien determinasi digunakan untuk mengukur seberapa jauh kemampuan model dalam menerangkan variasi variabel independen terhadap variabel dependen. Berdasarkan hasil pengolahan data dengan program SPSS, maka diperoleh hasil sebagai berikut:

\section{Tabel 22}

Hasil Uji Koefisien Determinasi

\begin{tabular}{|c|c|c|c|c|c|}
\hline \multirow[b]{2}{*}{ Model } & \multicolumn{4}{|c|}{ Model Summary } & \multirow[b]{2}{*}{ Durbin-Watson } \\
\hline & $R$ & R Square & $\begin{array}{l}\text { Adjusted } R \\
\text { Square }\end{array}$ & $\begin{array}{l}\text { Std. Error of } \\
\text { the Estimate }\end{array}$ & \\
\hline 1 &, $486^{\mathrm{a}}$ & ,237 & ,229 & 4,65917 & 2,129 \\
\hline
\end{tabular}

a. Predictors: (Constant), Electronic Word of Mouth

b. Dependent Variable: Keputusan Berkunjung

Berdasarkan tabel 22 dapat dilihat bahwa nilai koefisien determinasi $\left(\mathrm{R}^{2}\right)$ sebesar 0,237 atau 23,7\%. Nilai koefisien determinasi tersebut menjelaskan bahwa dalam penelitian ini pengaruh Electronic Word of Mouth terhadap keputusan berkunjung sebesar 23,7\%, sedangkan sisanya sebesar $76,3 \%$ dijelaskan oleh variabel lainnya yang tidak diteliti dalam penelitian ini.

\section{Uji Hipotesis Parsial (Uji-t)}

Sebelum melakukan uji t, terlebih dahulu mencari nilai tabel. Dalam penelitian ini tingkat signifikansi $(\alpha)$ sebesar 0,05 dengan derajat kebebasan $(\mathrm{df}=\mathrm{n}-\mathrm{k})$ yaitu $(\mathrm{df}=100-2=$ 98). Selanjutnya mencari nilai tabel menggunakan program excel dengan menggunakan rumus $=\operatorname{TINV}(0,05 ; 98)$, maka diperoleh nilai tabel sebesar 1,984. Berikut hasil olahan data uji t: 
Tabel 23

Hasil Uji t (Parsial)

\section{Coefficients $^{\mathbf{a}}$}

\begin{tabular}{|c|c|c|c|c|c|}
\hline & \multicolumn{2}{|c|}{ Unstandardized Coefficients } & \multirow{2}{*}{$\begin{array}{c}\text { Standardize } \\
d \\
\text { Coefficients } \\
\text { Beta }\end{array}$} & \multirow[b]{2}{*}{$t$} & \multirow[b]{2}{*}{ Sig. } \\
\hline Model & $\mathrm{B}$ & Std. Error & & & \\
\hline 1 (Constant) & 21,577 & 3,019 & & 7,146 &, 000 \\
\hline $\begin{array}{l}\text { Electronic Word of } \\
\text { Mouth }\end{array}$ & ,308 &, 056 & ,486 & 5,512 &, 000 \\
\hline
\end{tabular}

a. Dependent Variable: Keputusan Berkunjung

Pada tabel 23 hasil uji t (parsial) variabel Electronic Word of Mouth terhadap keputusan berkunjung menunjukkan nilai thitung sebesar 5,512 dan nilai Sig 0,000 sehingga dapat diartikan bahwa nilai thitung $>t_{\text {tabel }}(5,512>1,984)$ dan nilai Sig $(0,000<0,05)$, maka dapat disimpulkan dalam penelitian ini $\mathrm{H}_{0}$ ditolak dan $\mathrm{H}_{\alpha}$ diterima. Hal ini berarti Electronic Word of Mouth berpengaruh positif dan signifikan terhadap keputusan berkunjung ke Desa Wisata Cibeusi.

Berdasarkan hasil analisis yang dilakukan baik secara analisis deskriptif maupun analisis verifikatif, maka pembahasan hasil penelitian sebagai berikut :

\section{Pembahasan Electronic Word Of Mouth}

Berdasarkan hasil analisis deskriptif variabel independen yaitu Electronic Word of Mouth yang terdiri dari 7 dimensi dan 16 item pernyataan diperoleh skor rata-rata keseluruhan sebesar 3,92 dan dikategorikan baik. Perolehan rata-rata tertinggi diperoleh dari dimensi Concern for Other Consumers dengan pernyataan "Saya merekomendasikan ulang Desa Wisata Cibeusi ke orang lain dengan melakukan $e-W O M$ " dengan skor rata-rata sebesar 4,18. Sedangkan rata-rata terkecil diperoleh dari dimensi Venting Negative Feelings dengan pernyataan "Melalui e-WOM, saya bisa mendapatkan informasi negatif tentang Desa Wisata Cibeusi" dengan skor rata-rata sebesar 3,33.

\section{Pembahasan Keputusan Berkunjung}

Berdasarkan hasil analisis deskriptif variabel dependen yaitu keputusan berkunjung yang terdiri dari 6 dimensi dan 11 item pernyataan diperoleh skor rata-rata keseluruhan sebesar 4,04 dan dikategorikan baik. Perolehan rata-rata tertinggi diperoleh dari dimensi pemilihan brand dengan pernyataan "Saya berkunjung ke Desa Wisata Cibeusi karena keinginan melepas penat dari kegiatan sehari-hari" dengan skor rata-rata sebesar 4,37. Sedangkan rata-rata terkecil diperoleh dari dimensi pemilihan penyalur dengan pernyataan "Saya dapat menggunakan jasa seperti agen perjalanan untuk berkunjung ke Desa Wisata Cibeusi" dengan skor rata-rata sebesar 3,51. 


\section{Pengaruh Electronic Word Of Mouth Terhadap Keputusan Berkunjung}

Berdasarkan hasil dari analisis verifikatif pada analisis regresi linear sederhana didapatkan jawaban persamaan regresi sederhananya yaitu $\mathrm{Y}=21,577+0,308 \mathrm{X}$, hal ini menunjukan jika variabel Electronic Word of Mouth meningkat 1 satuan, maka nilai keputusan berkunjung pun akan meningkat sebesar 0,308. Dapat disimpulkan bahwa semakin tinggi Electronic Word of Mouth maka akan semakin tinggi keputusan berkunjung.

Dari hasil analisis koefisien korelasi, menghasilkan nilai sebesar 0,486 dengan signifikansi di level 0,01 (2-tailed). Nilai ini termasuk pada kategori sedang karena berada pada rentang $0,400-0,599$. Hal ini menunjukkan bahwa terdapat hubungan yang sedang antara Electronic Word of Mouth dengan keputusan berkunjung.

Sedangkan uji koefisien determinasi menghasilkan nilai R Square $\left(\mathrm{R}^{2}\right)$ sebesar 0,237 atau 23,7\%. Artinya dalam penelitian ini 23,7\% keputusan berkunjung dapat dijelaskan oleh variabel Electronic Word of Mouth, sedangkan sisanya sebesar 76,3\% dijelaskan oleh variabel lainnya yang tidak diteliti dalam penelitian ini seperti motivasi. Menurut Lestari dan Sunarti (2019:33) motivasi dapat mempengaruhi keputusan berkunjung secara signifikan sebesar $38,1 \%$.

Berdasarkan hasil uji t (parsial) hipotesis, menghasilkan nilai thitung sebesar 5,512 yang melebihi nilai tabel sebesar 1,984 dengan nilai signifikansi $0,000<0,05$, maka hipotesis yang terbukti dalam penelitian ini yaitu $\mathrm{H}_{0}$ ditolak dan $\mathrm{H}_{\alpha}$ diterima. Hal ini dapat diartikan bahwa Electronic Word of Mouth berpengaruh positif dan signifikan terhadap keputusan berkunjung ke Desa Wisata Cibeusi.

Hasil penelitian ini sejalan dengan hasil penelitian yang dilakukan oleh Heni Susilawati (2017) dengan Yudi Purnama Dani dan Thamrin (2019) yang menyatakan bahwa terdapat pengaruh yang positif dan signifikan antara Electronic Word of Mouth dengan keputusan berkunjung

\section{SIMPULAN}

1. Gambaran keseluruhan setiap pernyataan dari variabel Electronic Word of Mouth memperoleh rata-rata sebesar 3,92 dan dikategorikan baik. Dengan rata-rata tertinggi diperoleh dari salah satu pernyataan dimensi Concern for Other Consumers yaitu sebesar 4,18. Sedangkan rata-rata terkecil diperoleh dari salah satu pernyataan dimensi Venting Negative Feelings yaitu sebesar 3,33.

2. Gambaran keseluruhan setiap pernyataan dari variabel keputusan berkunjung memperoleh rata-rata sebesar 4,04 dan dikategorikan baik. Dengan rata-rata tertinggi diperoleh dari salah satu pernyataan dimensi pemilihan brand yaitu sebesar 4,37. Sedangkan rata-rata terkecil diperoleh dari salah satu pernyataan dimensi pemilihan penyalur yaitu sebesar 3,51.

3. Hasil penelitian menunjukkan bahwa, besarnya pengaruh Electronic Word of Mouth terhadap keputusan berkunjung berdasarkan hasil koefisien determinasi yaitu sebesar 0,237 atau $23,7 \%$, sedangkan $76,3 \%$ sisanya dipengaruhi oleh variabel lain yang tidak diteliti dalam penelitian ini. Hasil uji hipotesis secara parsial menyatakan bahwa variabel independen Electronic Word of Mouth mempunyai pengaruh yang positif dan signifikan terhadap variabel dependen keputusan berkunjung di Desa Wisata Cibeusi. Hal ini dapat dilihat dari hasil uji $t$ (parsial) yang menunjukkan nilai thitung $>t_{\text {tabel }}(5,512>1,984)$ dengan signifikansi $0,000<0,05$. 


\section{DAFTAR PUSTAKA}

A.J., Muljadi. (2012). Kepariwisataan dan Perjalanan. Jakarta: PT Raja Grafindo Persada. Ari, Setiyaningrum. (2015). Prinsip-prinsip Pemasaran. Yogyakarta: Andi Offset.

Arikunto, S. (2010). Prosedur Penelitian Suatu Pendekatan Praktik. Jakarta: Rineka Cipta.

Alma, B. (2016). Manajemen Pemasaran dan Pemasaran Jasa. Bandung: Cb Alfabeta.

Edison, E., Anwar, Y., \& Komariyah, I. (2017). Manajemen Sumber Daya Manusia. Bandung: Alfabeta.

Lestari, F.D., dan Sunarti (2019). Pengaruh Motivasi Terhadap Keputusan Berkunjung (Survei Pada Pengunjung Desa Wisata Pujon Kidul Kabupaten Malang). Jurnal Administrasi Bisnis, 70(1), 29-35.

Ghozali, I. (2016). Aplikasi Analisis Multivariete Dengan Program IBM SPSS 23 (Edisi 8). Semarang: Badan Penerbit Universitas Dipenogoro.

Goldsmith, R. E dan Horowitz, D. (2006). Measuring Motivations For Online Opinion Seeking. Journal of Interactive Advertising, 6(2), 3-14.

Gruen, T.W., Osmonbekov,T., Czaplewski, A. J (2006). eWOM: the impact of customer-tocustomer online know- how exchange on customer value and loyalty, Journal of Business Research, 59(4), 449-456.

Hasan, Ali. (2013). Marketing dan Kasus-Kasus Pilihan. Yogyakarta. CAPS (Center For Academic Publishing Service).

Hasan, Ali. (2015). Tourism Marketing. Yogyakarta. Center for Academic Publishing Service.

Hasan dan Setiyaningtiyas. (2015). Pengaruh Electronic Word Of Mouth Pada Media Sosial Facebook Terhadap Keputusan Berkunjung Ke Desa Wisata Nglanggeran Gunung Kidul. 13. 224-238. Diakses tanggal 4 September 2019 dari https://amptajurnal.ac.id.

Hennig-Thurau, T., Gwinner, K.P., Walsh, G. dan Gremler, D. D. (2004). Electronic Word-ofMouth Via Customer-Opinion Platforms: What Motivates Consumer to Articulate Themselves on the Internet. Journal of Interactive Marketing, Vol 18/No 1, 38-52. Diakses tanggal 24 September 2019 dari https://www.marketingcenter.de.

Husein, U. (2011). Metode Penelitian Untuk Skripsi dan Tesis Bisnis Edisi 11. Jakarta: PT Raja Grafindo Persada.

Humaira, A., dan Wibowo, L.A. (2016). Analisis Faktor Electronic Word Of Mouth (EWOM) Dalam Mempengaruhi Keputusan Berkunjung Wisatawan. Tourism and Hospitality Essentials (THE) Journal. 6. 1049-1060. Diakses dari http://ejournal.upi.edu.

Illah, A.N., Sularso, R.A, dan Irawan, B. (2019). Pengaruh Citra Destinasi dan E-WoM di Media Sosial Instagram serta Persepsi Konsumen Terhadap Keputusan Berkunjung ke Objek Wisata B29 di Kabupaten Lumajang. 6. 164-170. e-Journal Ekonomi Bisnis dan Akuntansi. Diakses dari https://jurnal.unej.ac.id.

Kotler, P., Lane, Keller. (2016). Marketing Management, 15th, Edition. Pearson Education, Inc.

Kotler, P and Armstrong. (2016). Principle of Marketing, 16th edition, Pearson Education.

Kotler, P and Amstrong. G. (2018). Principles Of Marketing, 17th Ed, Global Edition. Pearson Education, New Jersey.

Muksin, D.R.M., dan Sunarti. (2018). Pengaruh Motivasi Terhadap Keputusan Berkunjung Wisatawan di Ekowisata Mangrove Wonorejo Surabaya. Jurnal Administrasi Bisnis. 
55(1). Diakses tanggal $25 \quad$ September 2019 dari administrasibisnis.studentjournal.ub.ac.id.

Prasetyo, B dan Jannah, LN. (2010). Metode Penelitian Kuaqntitatif Teori dan Aplikasi. Jakarta: PT Raja Grafindo Persada.

Rizki, R.S., dan Nurani N. (2019). Word of Mouth Terhadap Keputusan Berkunjung di Tahura Ir. H. Djuanda. Jurnal Riset Bisnis dan Manajemen, 12(1), 43-49.

Rambat, Lupiyoadi. (2013). Manajemen Pemasaran Jasa, Salemba Empat. Jakarta.

Santoso, S. (2012). Panduan Lengkap SPSS Versi 20. Jakarta: PT Elex Media Komputindo

Sedarmayanti dan Hidayat, S. (2011). Metodologi Penelitian. Bandung: Mandar Maju

Setiadi, Nugroho J. (2010). Perilaku Konsumen. Cetakan 4. Edisi Revisi. Jakarta: Kencana.

Shinta, Agustina. (2011). Manajemen Pemasaran. Malang: UB Press.

Silalahi, Uber. (2011). Asas-Asas Manajemen. Bandung: Refika Aditama.

Sugiyono. (2014). Metode Penelitian Pendidikan Kuantitatif, Kualitatif, dan R\&D. Bandung: Alfabeta.

Sugiyono. (2016). Metode Penelitian Kuantitatif, Kualitatif, dan R\&D. Bandung:

Alfabeta, CV.

Sugiyono. (2017). Metode Penelitian Kuantitatif, Kualitatif, dan R\&D. Bandung:

Alfabeta, CV.

Susilawati, H. (2017). Jurnal Khasanah Ilmu. Pengaruh Electronic Word Of Mouth Terhadap Keputusan Berkunjung Di Sindu Kusuma Edupark. 8. 32-38. Diakses tanggal 4 September 2019 dari https://ejournal.bsi.ac.id.

Suwantoro, G. (2018). Dasar-Dasar Pariwisata. Yogyakarta: Andi.

Tjiptono, F. (2014). Pemasaran Jasa Prinsip, Penerapan dan Penelitian. Yogyakarta: Andi Offset.

Undang-Undang Republik Indonesia Nomor 10 Tahun 2009 Tentang Kepariwisataan.

Wibowo, A. (2015). Pengaruh Electronic Word of Mouth dan Brand Image Terhadap Purchase Intention Pada Konsumen Smartphone Samsung yang Berbasis Android. Jurnal Ilmu Manajemen. 12. 71-88. Diakses tanggal 24 September 2019 dari https://journal.uny.ac.id.

Zeithaml, V.A., \& M.J. Bitner, \& D.D. Gremler. (2013). Services Marketing: Integrating Customer Focus Across the Firm 6thed. Mc.Graw-Hill. Boston. 